\title{
School context in the transition from the early years to the final years of Elementary Education
}

\author{
Contexto escolar na transição dos anos iniciais para \\ os anos finais do Ensino Fundamental
}

Cynthia CASSONI ${ }^{1}$ (iD) 0000-0003-3550-7840

Edna Maria MARTURANO² (iD) 0000-0002-1545-0093

Anne Marie FONTAINE ${ }^{3}$ iD 0000-0001-9232-8692

Vanessa Barbosa Romera LEME' (iD) 0000-0002-9721-0439

\begin{abstract}
The transition between the two cycles of Elementary School is a process with anticipations and expectations in the 5th as well as demands and adaptations in the 6th year. The objective of this paper is to investigate the effects of the transition taking into account the nature of the transition. A prospective study was carried out with two data collections (5th and 6th grade). A total of 379 public-school students (212 girls), with a mean age of 10.6 years $(S D=0.91)$, were enrolled at the beginning of the study. The instruments used were Brazil Test, Child Stress Scale, Social Skills Assessment System, Self-Concept Assessment Questionnaire, and Multidimensional Life Satisfaction Scale for Children. When comparing the two grades, children who did not change schools showed more stability, especially in academic self-concept; those enrolled in municipal schools showed a greater decrease in self-concept and satisfaction with life. School change seems to increase the demands of transition.
\end{abstract}

Keywords: Emotional adjustment; Psichological adaptation; Social adjustment.

$\checkmark \nabla \nabla$

${ }^{1}$ Universidade do Estado do Rio de Janeiro, Departamento de Psicologia, Programa de Pós-Graduação em Psicologia Social. R. São Francisco Xavier, 524, Maracanã, 24030-060, Rio de Janeiro, RJ, Brasil. Correspondence to: C. CASSONI. E-mail: <cynthia.cassoni@gmail.com>.

${ }^{2}$ Universidade de São Paulo, Faculdade de Medicina de Ribeirão Preto, Programa de Pós-Graduação de Psicologia. Ribeirão Preto, SP, Brasil.

${ }^{3}$ Universidade do Porto, Centro de Psicologia, Faculdade de Psicologia e Ciências da Educação. Porto, Portugal.

Support: Coordenação de Aperfeiçoamento de Pessoal de Nivel Superior (Process no 99999.006432/2015-08) and Conselho Nacional de Desenvolvimento Científico e Tecnológico (Process n 462540/2014-6, nº 301857/2015-6).

Article based on the doctoral dissertation of C. CASSONI, entitled "Transição escolar das crianças do $5^{\circ}$ para o $6^{\circ}$ ano do ensino fundamental". Universidade de São Paulo and Universidade do Porto, 2017.

$\boldsymbol{\nabla} \boldsymbol{\nabla} \boldsymbol{V}$

How to cite this article

Cassoni, C., Marturano, E. M., Fontaine A. M., \& Leme, V. B. R. (2020). School context in the transition from the early years to the final years of Elementary Education. Estudos de Psicologia (Campinas), 37, e190049. http://dx.doi.org/10.1590/1982-0275202037e190049 


\section{Resumo}

A transição entre os dois ciclos do Ensino Fundamental é um processo com antecipações e expectativas no $5^{\circ}$ e demandas e adaptações no $6^{\circ}$ ano. O objetivo deste trabalho é investigar efeitos da transição levando em consideração a natureza da transição. Realizou-se um estudo prospectivo com duas coletas de dados ( $5^{\circ}$ e $6^{\circ}$ ano). Participaram 379 alunos de escolas públicas (212 meninas), com média de idade de 10,6 anos ( $D P=0,91)$ no início da pesquisa. Utilizou-se a Prova Brasil, Escala de Stress Infantil, Sistema de Avaliação de Habilidades Sociais, Questionário para Avaliação do Autoconceito e Escala Multidimensional de Satisfação de Vida para Crianças. Nas comparações entre os anos, crianças que não mudaram de escola apresentaram maior estabilidade, sobretudo no autoconceito acadêmico; as encaminhadas para escolas municipais apresentaram maior decréscimo no autoconceito e na satisfação com a vida. A mudança de escola parece amplificar as demandas da transição.

Palavras-chave: Ajustamento emocional; Orientação psicológica; Ajustamento social.

Students between the ages from ten to thirteen experience a period of significant physical, cognitive and interpersonal changes when changing from Elementary School I (ESI) to Elementary School II (ESII) (terms used in Brazil). This article focuses on the transition between the two levels and the possible psychological effects on the child.

Between the $5^{\text {th }}$ and $6^{\text {th }}$ grade, transition to ESII means changes in the organization of curriculum content, which becomes more compartmentalized into specific subjects; as the number of teachers increases, the teacher-student relationship may become less centralized and require more student autonomy. For students attending the public-school system, starting the $6^{\text {th }}$ grade may or may not require a change of school and a change of school may mean changing from a municipal to a state school. According to the 2017 School Census, changes are common and the municipal network, the main responsible for elementary education in Brazil, is responsible for $69.8 \%$ of schools in the early years of the cycle and $47.2 \%$ in the final years. In this context, it is assumed that the demands of the transition on students are greater, as they must adapt to a different school culture and build new relationships with peers and teachers.

The experience of school transition between the ages of 11 and 13 years has been a subject of empirical research since the 1960s (Symonds \& Galton, 2014), and it still attracts the attention of developmental researchers. Longitudinal studies have either detected a decline in performance (Forrest, Bevans, Riley, Crespo, \& Louis, 2013; Ryan, Shim, \& Makara, 2013) or stability during transition (Sebanc, Guimond, \& Lutgen, 2014). Akos, Rose, and Orthner (2015), following up students from the $3^{\text {rd }}$ to $8^{\text {th }}$ grade, interpret the decline as a momentary reduction in student achievement restricted to the post-transition period.

While temporary adverse effects have been identified in school performance, the study on selfperception during transition is divergent. Metsäpelto et al. (2017) found, in longitudinal research, a decline in self-concept in mathematics from $6^{\text {th }}$ to $7^{\text {th }}$ grade. Along the same lines, Arens, Yeung, Craven, Watermann, and Hasselhorn (2013) observed that students in the $6^{\text {th }}$ grade (in the post-transition grade) showed lower academic self-concept than $5^{\text {th }}$ grade students (previous grade), but did not differ in dimensions of self-concept regarding physical appearance and relationship with peers. In contrast, Coelho and Romão (2017) found not only a decrease in academic self-concept in the $5^{\text {th }}$ grade, but also a decline in the social, emotional, physical and family dimensions. In their review study focusing on academic self-concept, Symonds and Galton (2014) found controversial results: the analyzed research showed both an increase and reduction in self-perception after transition. The authors interpreted this variation as suggestive of instability and concluded that different trajectories could be established depending on students' personal and contextual resources, such as selfesteem, school engagement, and family support.

Therefore, the literature review suggests that the transition between ESI and ESII is not a one-off event; it is a long-haul process that begins with anticipations and expectations in the $5^{\text {th }}$ grade and continues 
with demands and adaptations in the $6^{\text {th }}$ grade (Neal, Rice, Ng-Knight, Riglin, \& Frederickson, 2016). The process is not uniform either, as it may have variations in its characteristics, such as school transfer. Thus, understanding the possible impacts of this experience can be broadened if an approach of the relationship between specific contextual changes and the children's development is adopted (Symonds \& Galton, 2014). This perspective was considered in the present study to investigate possible different transition effects in the public-school system in Brazil, in which the transition to the second cycle of Elementary School (ES) can occur without changing schools or changing to a municipal or state school.

Some research results corroborate this assumption. Symonds and Galton (2014) report that transition anxiety is lower when differences between the child's previous school and post-transition school are smaller and familiarity with peers and teachers is associated with lower instability of academic self-concept after transition. Neal et al. (2016) found that different strategies adopted by the child's previous school to prevent transition anxiety (strategies such as talking to children about the transition, visits to the post-transition school, and expanding support networks) resulted in different levels of effectiveness after the transition.

In line with the focus on contextual changes and student development, we chose to use the Bioecological Model of Human Development (BMHD) (Bronfenbrenner \& Morris, 1998). The systemic perspective offered by the BMHD conceives development as resulting from continuous interactions between multiple levels and instances of action, included in these interactions, as an active participant, the person in development. The study of issues related to school transitions finds in this model an adequate conceptual support, related to the notion of ecological transition.

According to Bronfenbrenner (1996), "an ecological transition occurs whenever one's position in the ecological environment is changed as a result of a change in role, environment or both" (Bronfenbrenner, 1996, p.22). From this perspective, the transition from the $5^{\text {th }}$ to $6^{\text {th }}$ grade can be seen as an ecological transition because it implies a change in role (student of the $1^{\text {st }}$ cycle of ES to a student of the $2^{\text {nd }}$ cycle of ES) and environment (from an integrated system with a single teacher to a compartmentalized system with more teachers). School transitions can thus be conceived as related to these changes in role and context provided that a third fundamental component in the bioecological approach is considered: the perspective of the person in development.

In this respect, Bronfenbrenner (1996, p.6) emphasizes that "environment is important for behavior and development as it is perceived and not as objective reality". When applied to the study of the transition to EFIl, this statement implies that the way children deal with the transition challenges is directly related to the way they perceive the microsystems in which they are included (school, family and peers) and how they perceive themselves in these contexts.

Therefore, a conceptual scheme is proposed, inspired by the notion of ecological transition, focusing on the change in role definitions, change in context and the children's perceptions about themselves and their surroundings. Taking into account the four components of the bioecological model of human development (Bronfrenbrenner \& Morris, 1998), process, person, context and time, the present study gives priority to the person and context variables that, from the perspective of time, can contribute to the understanding of the processes involved in the transition. The perspective of time was achieved by surveying children before and after the transition. The person variables consisted of four sets of variables representing possible responses of children to adaptive demands of transition: (a) academic performance, i.e. performance in tests that evaluate the mastery of the syllabus of each school level; (b) stress symptoms, i.e. the set of body reactions when exposed to any stimuli that irritates, frightens or makes one happy, which may be psychological (anxiety and nightmares) or physical, (abdominal pain and nausea) (Lipp \& Lucarelli, 2008); (c) social skills, defined as social behaviors valued in culture, with a high probability of favorable outcomes for the individual and the group, which may contribute to competent performance in interpersonal tasks (Pereira-Guizzo, A. Del Prette, Dell Prette, \& Leme, 2018); (d) self-concept, established as the individuals' perception of themselves 
formed through experience with the environment, interactions with significant others, and attributions of one's own behavior (Marsh, Relich, \& Smith, 1983).

Context was represented by the nature of the transition and the children's perceptions of their social surroundings. The nature of transition, a central variable in this study, identified three possibilities of transition in Brazilian public education: no change of school; change to a municipal school; or change to a state school. The children's perceptions of their social surroundings was focused on the perspective of their satisfaction with family, school and friends, based on the prediction that an ecological transition will be healthier if the child realizes that he or she is receiving support to deal with ongoing changes from significant people (Bronfenbrenner, 1996; Oriol, Torres, Miranda, Bilbao, \& Ortúzar, 2017). Given the absence of longitudinal studies in the national context of transition in the final years of the ES that take into account the nature of the transition, the aim of the study was to investigate the impact of transition between ESI and ESII on academic performance, symptoms of stress, social skills, self-concept, and satisfaction with support, considering the nature of the transition (with or without school change, with or without change in school network).

\section{Method}

\section{Participants}

This is a prospective study consisting of two phases of data collection in the $5^{\text {th }}$ and $6^{\text {th }}$ grade of ES. A total of 379 children ( 212 girls) with a mean age of 10.6 years $(S D=0.91)$ at the beginning of the research participated in the two data collections. The initial sample of 415 students were randomly selected by the draw from $5^{\text {th }}$ grade classes in 15 ES municipal schools in a city in the state of São Paulo. In the following year, the remaining participants $(N=379)$ moved to six municipal and eight state schools. The score for Índice de Desenvolvimento da Educação Básica (IDEB, Basic Education Development Index) varied greatly in both municipal schools in the $5^{\text {th }}$ grade and in municipal and state schools in the $6^{\text {th }}$ grade. In the $5^{\text {th }}$ grade, IDEB ranged from 5.4 to 7.6 with the highest concentration between 6.0 and 7.0 (10 schools). In the $6^{\text {th }}$ grade, the IDEB of municipal schools ranged from 5.2 to 7.6 and state schools ranged from 4.0 to 5.6 with the highest concentration below 5.0 (six schools).

\section{Instruments}

The Avaliação Nacional do Rendimento Escolar (ANRESC, National Assessment of School Performance), known as Prova Brasil, is part of the Sistema de Avaliação da Educação Básica (SAEB, Basic Education Assessment System) and was used to assess academic performance. The assessment consists of 56 questions with right/ wrong answers to assess notions of Portuguese and mathematics. The score is the sum of the correct answers that range from 0 to 28 in Portuguese and math and from 0 to 56 for the total score.

The Child Stress Scale (CSS) was used to assess stress symptoms (Lipp \& Lucarelli, 2008). The aim of the scale is to identify the frequency and intensity with which children aged 6-14 experience stress symptoms (psychological, physical or both). The scale consists of 35 5-point Likert-type items grouped into four factors: physical reactions, psychological reactions, psychological reactions with a depressive component and psychophysiological reactions. Based on the confirmatory factor analysis performed for this study, two factors were maintained: psychological reactions and psychological reactions with a depressive component $\left(\chi^{2} / d f\right.$. $=1.776$, Comparative Fit Index $(\mathrm{CFI})=0.930$, Goodness of Fit Index $(\mathrm{GFI})=0.941$, Root Mean Residual $(R M R)=0.047$, Root Mean Square Error of Approximation $(R M S E A)=0.045$; total alpha was 0.830 .

Social skills were assessed using the Social Skills Rating System (SSRS), Brazilian version (Freitas \& Del Prette, 2015). The instrument has three versions to assess children aged three to 18 years: parental evaluation, 
teacher assessment, self-assessment by the child. It consists of 20 3-point Likert-type items ranging from never, sometimes and very often, grouped into four factors: responsibility/cooperation (behaviors that demonstrate commitment to tasks and people in the school environment), empathy (behaviors that show interest, respect and concern for others), self-control (behaviors that demonstrate mastery over one's own emotional reactions) and assertion (behaviors that question unfair rules, emotional self-control when dealing with class discussions and disagreeing with adults, greeting people and expressing opinions) (Freitas \& Del Prette, 2015). The confirmatory factor analysis performed in this study indicated the need to exclude self-control and assertion factors due to the low internal consistency. The indices obtained by the dimensions responsibility/ cooperation and empathy were: $\chi^{2} / d f .=2.700, \mathrm{CFI}=0.908, \mathrm{GFI}=0.960, \mathrm{RMR}=0.052, \mathrm{RMSEA}=0.067$ and $\alpha=0.750$.

Self-concept was assessed using the Self-Description Questionnaire 1 (SDQ1), which assumes that the instrument construct is multidimensional and hierarchically organized (Marsh et al., 1983). It was adapted to the Brazilian context (Gardinal-Pizato, 2010), and assesses the dimensions of self-concept in children aged seven to 12 years. The 76-item questionnaire assesses: overall self-concept; academic self-concept (composed by the math and Portuguese self-concept scales and general school); nonacademic self-concept (consisting of four scales: self-concept in the relationship with parents and self-concept in the relationship with friends, which form the social self-concept; physical appearance and physical competence, which form the physical self-concept). Items consist of 64 positive affirmations about one's self, for example, "I learn math really fast," "I get along with my parents," and 12 negative affirmations about one's self (inverted items), for example, "I can't do anything well", "Most children my age have more friends than I do". Each item is answered on a fourpoint Likert scale: totally agree to totally disagree. Confirmatory factor analysis provided indices for the sample of this study: global self-concept, $\chi^{2} / d f$. $=3.426, \mathrm{CFI}=0.913, \mathrm{GFI}=0.972, \mathrm{RMSEA}=0.080, \mathrm{RMR}=0.048$ and alpha 0.62; academic self-concept, $\chi^{2} / d f .=2.780, \mathrm{CFI}=0.904, \mathrm{GFI}=0.874, \mathrm{RMSEA}=0.069, \mathrm{RMR}=0.056$ and alpha 0.88; non-academic self-concept, $\chi^{2} / d f$. $=1.779, \mathrm{CFI}=0.908, \mathrm{GFI}=0.909, \mathrm{RMSEA}=0.045, \mathrm{RMR}=0.054$ and alpha 0.86. The total alpha was 0.900 .

Satisfaction with family, school and peers was assessed using three factors from the Multidimensional Life Satisfaction Scale for Children (MSLSS) (Giacomoni \& Hutz, 2008). The 50-item instrument was designed for children aged seven to 12 years old and distributed into six factors: family (descriptors of a healthy, harmonious, affective family environment, satisfactory relationships as well as indicators of family satisfaction); friendship (focuses on peer relationships, level of satisfaction with these relationships and some indicators of leisure, fun and supportive situations); school (describes the importance of school, school environment, interpersonal relationships and level of satisfaction with environment); self (positive characteristics such as self-esteem, good mood, ability to relate, ability to show affection); comparative self (grouped items that are characterized by comparative evaluations with peers), and non-violence (content associated with aggressive behaviors). For each item, the answer indicates the degree of agreement with the statement rated on a five-point Likert-type scale that ranges from completely agree, partially agree, completely disagree. In the confirmatory factor analysis, five dimensions were maintained in the model and the non-violence factor was excluded: $\chi^{2} / d f=1.927, \mathrm{CFI}=0.906, \mathrm{GFI}=0.878, \mathrm{RMR}=0.062$ and RMSEA $=0.050$ and total alpha of 0.86 .

\section{Procedure}

After approval by the Research Ethics Committee, CAAE No. 27855914.5.0000.5407, assessments were conducted in three group sessions at schools during class time. Each session lasted approximately one hour and 30 minutes. The first collection took place in August and September 2014 and the second one took place during the last week of July until September 2015. 


\section{Data analysis}

The Analysis of Variance (ANOVA) was used to identify possible variations in academic performance, stress symptoms, social skills, self-concept, and life satisfaction in the $5^{\text {th }}$ grade (considering transition expectations) and the $6^{\text {th }}$ grade (after transition) due to different transitions. In the city where the research was conducted the students' school is pre-established so the students know in the $5^{\text {th }}$ grade which school they will attend if they are promoted. Based on student migration, three groups were formed: Trans1, children who remained in the same municipal school in the $6^{\text {th }}$ grade $(n=75)$; Trans2, those who changed to another municipal school in the $6^{\text {th }}$ grade $(n=100)$; Trans3, those who changed to a state school $(n=204)$.

The mixed repeated-measures ANOVA at a significance level of 0.05 was used to investigate the effects of interaction between time and the school transition group on the following variables: academic performance, stress symptoms, social skills, self-concept and life satisfaction. The ANOVA assumptions were confirmed for all variables using the Kolmogorov-Smirnov test with Lilliefors correction and Mauchly test. To evaluate the effect size of the differences, a small effect was considered if $\eta^{2} p \leq 0.05$ and $d \leq 0.20$; a medium effect if $\eta^{2} p$ ranged from 0.051 to 0.25 and d between 0.2 and 0.5 ; a large effect if $\eta^{2} p$ was between 0.26 and 0.50 and $d$ between 0.50 and 1 ; and a very large effect if $\eta^{2} p>0.50$ and $d>1$ (Marôco, 2014).

\section{Results}

In this section, only results with statistical significance are commented. The tables show results of comparisons between the three transition groups in the $5^{\text {th }}$ and $6^{\text {th }}$ grades, variations between the two moments, and the interaction effects between time and type of transition. The specification of the differences between groups is shown in the tables. The specification of variations between the moments as well as interaction effects are pointed out in the text.

The results regarding academic performance, stress symptoms and social skills are shown in Table 1. In the $5^{\text {th }}$ grade, significant differences were observed between the groups in all variables. Most of the differences were found between Trans2 group, which consisted of students who were expected to change to another municipal school, and Trans3, the group of children who expected to change to a state school; when comparing the groups, Trans2 showed higher mean values in math, responsibility/cooperation, empathy, and total social skills, while Trans3 showed a higher mean value for stress symptoms. The Trans3 group, in comparison with the other groups, showed the lowest mean values for Portuguese and total academic performance. In the $6^{\text {th }}$ grade, Trans 2 maintained the advantage over Trans3 for Portuguese and overall academic achievement; Trans1 group, which did not change schools during the transition, presented a higher mean value than Trans3 for social skills (total).

The results of mixed-repeated measures ANOVA revealed a variation between the $5^{\text {th }}$ and $6^{\text {th }}$ grade only for total social skills but there was a reduction in all groups. The effect of interaction between time and school transition, with a small size effect for total social skills, indicated that the decrease was more significant in the Trans2 group, when students changed to another municipal school.

Table 2 shows the results regarding the dimensions of self-concept. In the $5^{\text {th }}$ grade, Trans 1 presented lower mean values in the dimensions of academic self-concept: it significantly differed from the other groups regarding the mean values of Portuguese self-concept, and Trans2 differed in the general school self-concept and math self-concept. The two groups also differed in total self-concept. The Trans 2 group presented a higher mean value than Trans3 for self-concept in the relationship with parents. All the differences were of small size effect. In the $6^{\text {th }}$ grade there were significant differences, with a small effect size, between the mean values for the general school self-concept, Portuguese self-concept and math self-concept. In the general school self-concept, Trans3, students who changed to state schools, showed a higher mean value 
than Trans2, students who changed to municipal schools. Trans1, students who did not change schools, presented a lower mean value than the other groups for Portuguese self-concept, while the mean value for the math self-concept was higher than the one in the Trans2 group.

Between the $5^{\text {th }}$ and $6^{\text {th }}$ grades, there is a variation in the mean value for the general school self-concept, math, relationship with parents and total scores. The general trend was a decrease after transition. In the same dimensions, the analysis indicated an interaction effect between time and type of transition. In the general school self-concept, in which all groups showed a significant decrease in the mean value between the $5^{\text {th }}$ and $6^{\text {th }}$ grades, the interaction effect was significantly lower in the Trans2 group - those who changed to a municipal school. In the math self-concept as well as in the total self-concept, the group that did not change schools (Trans1) did not present significant changes between the $5^{\text {th }}$ and $6^{\text {th }}$ grades, unlike the Trans 2 and Trans3 groups in which there is a decrease. The interaction effect on the self-concept in the relationship with parents results from the fact that only the Trans 2 group showed a significant decrease from $5^{\text {th }}$ to $6^{\text {th }}$ grade.

Table 1

Comparisons of the mean values for academic achievement, stress symptoms, and social skills in the $5^{\text {th }}$ and $6^{\text {th }}$ grades according to school transition

\begin{tabular}{|c|c|c|c|c|c|c|c|c|c|}
\hline \multirow{2}{*}{ Variable } & & & \multirow{2}{*}{$\begin{array}{l}\text { Trans1 } \\
(\mathrm{n}=75)\end{array}$} & \multirow{2}{*}{$\begin{array}{c}\text { Trans2 } \\
(n=100)\end{array}$} & \multirow{2}{*}{$\begin{array}{c}\text { Trans3 } \\
(n=204)\end{array}$} & \multirow{2}{*}{$\begin{array}{c}F \\
(2,376)\end{array}$} & \multirow{2}{*}{$\eta_{\mathrm{p}}^{2}$} & \multicolumn{2}{|c|}{ Interaction effect } \\
\hline & & & & & & & & $F(2,376)$ & $\eta_{0}^{2}$ \\
\hline \multirow[t]{4}{*}{ Portuguese } & 5 & $M$ & $14.28^{\mathrm{a}}$ & $15.17^{a}$ & $12.53^{\mathbf{b}}$ & $11.04 * * *$ & 0.05 & 0.59 & 0.00 \\
\hline & & $(S D)$ & $(4.82)$ & $(4.51)$ & $(4.95)$ & & & & \\
\hline & 6 & $M$ & $15.69^{\mathrm{ab}}$ & $17.40^{\mathrm{a}}$ & $14.26^{\mathbf{b}}$ & $12.22 * * *$ & 0.06 & & \\
\hline & & $(S D)$ & $(5.40)$ & $(4.06)$ & $(5.65)$ & & & & \\
\hline \multirow[t]{4}{*}{ Math } & 5 & $M$ & $16.29^{\mathrm{ab}}$ & $16.72^{\mathrm{a}}$ & $15.11^{b}$ & $6.09 * *$ & 0.03 & 0.37 & 0.00 \\
\hline & & (SD) & $(4.11)$ & $(4.21)$ & $(3.92)$ & & & & \\
\hline & 6 & $M$ & $17.69^{\mathrm{ab}}$ & $18.37^{a}$ & $16.97^{b}$ & $4.17^{*}$ & 0.02 & & \\
\hline & & $(S D)$ & $(4.62)$ & $(3.62)$ & $(3.98)$ & & & & \\
\hline \multirow{4}{*}{$\begin{array}{l}\text { Overall academic } \\
\text { achievement }\end{array}$} & 5 & $M$ & $30.57^{a}$ & $31.89^{a}$ & $27.70^{\mathbf{b}}$ & $10.49 * * *$ & 0.05 & 0.45 & 0.00 \\
\hline & & $(S D)$ & $(8.34)$ & $(7.58)$ & $(7.91)$ & & & & \\
\hline & 6 & $M$ & $33.39^{\mathrm{ab}}$ & $35.77^{a}$ & $31.24^{\mathrm{b}}$ & $10.76 * * *$ & 0.05 & & \\
\hline & & (SD) & $(8.88)$ & $(6.54)$ & $(8.44)$ & & & & \\
\hline \multirow[t]{4}{*}{ Stress symptoms } & 5 & $M$ & $1.10^{\mathrm{ab}}$ & $0.97^{\mathbf{b}}$ & $1.16^{\mathrm{a}}$ & $2.95^{*}$ & 0.01 & 2.87 & 0.01 \\
\hline & & $(S D)$ & $(0.62)$ & $(0.67)$ & $(0.66)$ & & & & \\
\hline & 6 & $M$ & 1.27 & 1.27 & 1.26 & 0.00 & 0.00 & & \\
\hline & & $(S D)$ & $(0.76)$ & $(0.77)$ & $(0.70)$ & & & & \\
\hline \multirow{4}{*}{$\begin{array}{l}\text { Responsability/ } \\
\text { cooperation }\end{array}$} & 5 & $M$ & $1.48^{\mathrm{ab}}$ & $1.59^{a}$ & $1.46^{\mathrm{b}}$ & $3.44^{*}$ & 0.01 & 2.59 & 0.01 \\
\hline & & $(S D)$ & $(0.42)$ & $(0.35)$ & (0.39) & & & & \\
\hline & 6 & $M$ & 1.40 & 1.35 & 1.32 & 0.70 & 0.00 & & \\
\hline & & $(S D)$ & $(0.46)$ & $(0.44)$ & $(0.45)$ & & & & \\
\hline \multirow[t]{4}{*}{ Empathy } & 5 & $M$ & $1.54^{\mathrm{ab}}$ & $1.62^{\mathrm{a}}$ & $1.46^{\mathbf{b}}$ & $5.80 * *$ & 0.03 & 1.90 & 0.01 \\
\hline & & $(S D)$ & $(0.36)$ & $(0.36)$ & (0.39) & & & & \\
\hline & 6 & $M$ & 1.46 & 1.44 & 1.38 & 1.28 & 0.00 & & \\
\hline & & (SD) & $(0.34)$ & $(0.38)$ & $(0.42)$ & & & & \\
\hline \multirow[t]{6}{*}{ Overall social skills } & 5 & $M$ & $1.51^{\mathrm{ab}}$ & $1.60^{a}$ & $1.46^{\mathrm{b}}$ & $6.76 * *$ & 0.03 & $3.40 *$ & 0.01 \\
\hline & & (SD) & $(0.32)$ & $(0.28)$ & $(0.32)$ & & & & \\
\hline & 6 & $M$ & $1.43^{\mathrm{a}}$ & $1.40^{\mathrm{ab}}$ & $1.36^{\mathbf{b}}$ & $1.42 *$ & 0.00 & & \\
\hline & & (SD) & $(0.31)$ & $(0.32)$ & $(0.34)$ & & & & \\
\hline & & & $3.97 *$ & $33.35 * * *$ & $17.99 * * *$ & & & & \\
\hline & & & 0.50 & 1.0 & 1.0 & & & & \\
\hline
\end{tabular}

Note: ${ }^{*} p<0.05, * * p<0.01, * * * p<0.001$. The mean values on the same line with different letters are significantly different from each other. Trans1: remained in the same municipal school; Trans2: changed to another municipal school; Trans3: changed to another state school. M: Mean, SD: Standard Deviation. 
Table 2

Comparisons between the mean values for self-concept in $5^{\text {th }}$ and $6^{\text {th }}$ grades according to school transition

\begin{tabular}{|c|c|c|c|c|c|c|c|c|c|}
\hline \multirow{2}{*}{ Variable } & & & \multirow{2}{*}{$\begin{array}{c}\text { Trans1 } \\
(n=75)\end{array}$} & \multirow{2}{*}{$\begin{array}{c}\text { Trans2 } \\
(\mathrm{n}=100)\end{array}$} & \multirow{2}{*}{$\begin{array}{c}\text { Trans3 } \\
(n=204)\end{array}$} & \multirow{2}{*}{$\begin{array}{c}F \\
(2,376)\end{array}$} & \multirow{2}{*}{$\eta_{\mathrm{p}}^{2}$} & \multicolumn{2}{|c|}{ Interaction effect } \\
\hline & & & & & & & & $F(2,376)$ & $\eta_{\mathrm{p}}^{2}$ \\
\hline \multirow[t]{6}{*}{ School in general } & \multirow[t]{2}{*}{5} & $M$ & $2.94^{\mathrm{b}}$ & $3.27^{\mathrm{a}}$ & $3.12^{\mathrm{ab}}$ & $5.91 * *$ & 0.03 & \multirow[t]{6}{*}{$8.94 * * *$} & \multirow[t]{6}{*}{0.04} \\
\hline & & $(S D)$ & $(0.65)$ & $(0.59)$ & $(0.62)$ & & & & \\
\hline & \multirow[t]{2}{*}{6} & $M$ & $2.69^{\mathrm{ab}}$ & $2.69^{b}$ & $2.90^{\mathrm{a}}$ & \multirow[t]{4}{*}{$4.03 *$} & \multirow[t]{4}{*}{0.02} & & \\
\hline & & $(S D)$ & $(0.75)$ & $(0.69)$ & $(0.69)$ & & & & \\
\hline & \multicolumn{2}{|c|}{$F(1.376)$} & $8.81 * *$ & $65.21 * * *$ & $19.03 * * *$ & & & & \\
\hline & \multicolumn{2}{|c|}{$\pi$} & 0.84 & 1.0 & 0.99 & & & & \\
\hline \multirow[t]{4}{*}{ Portuguese/ verbal } & \multirow[t]{2}{*}{5} & $M$ & $2.84^{\mathrm{b}}$ & $3.19^{a}$ & $3.09^{a}$ & $6.72 * *$ & 0.03 & \multirow[t]{4}{*}{0.61} & \multirow[t]{4}{*}{0.00} \\
\hline & & $(S D)$ & $(0.60)$ & $(0.63)$ & $(0.67)$ & & & & \\
\hline & \multirow[t]{2}{*}{6} & $M$ & $2.66^{\mathbf{b}}$ & $3.02^{\mathrm{a}}$ & $3.00^{\mathrm{a}}$ & $6.81 * *$ & 0.03 & & \\
\hline & & $(S D)$ & $(0.74)$ & $(0.75)$ & $(0.72)$ & & & & \\
\hline Math & 5 & $M$ & $3.03^{b}$ & $3.35^{\mathrm{a}}$ & $3.21^{\mathrm{ab}}$ & $4.83 * *$ & 0.02 & $16.76 * * *$ & 0.08 \\
\hline & & $(S D)$ & $(0.70)$ & $(0.60)$ & $(0.67)$ & & & & \\
\hline & 6 & $M$ & $3.13^{a}$ & $2.78^{b}$ & $2.93^{\mathrm{ab}}$ & $4.47 *$ & 0.02 & & \\
\hline & & $(\mathrm{SD})$ & $(0.74)$ & $(0.83)$ & $(0.75)$ & & & & \\
\hline & & 76) & 1.31 & $56.58 * * *$ & $27.37 * * *$ & & & & \\
\hline & & & 0.20 & 1.0 & 1.0 & & & & \\
\hline Physical appearance & 5 & $M$ & 3.37 & 3.39 & 3.40 & 0.04 & 0.00 & 2.68 & 0.01 \\
\hline & & $(S D)$ & $(0.67)$ & $(0.65)$ & $(0.56)$ & & & & \\
\hline & 6 & $M$ & 3.34 & 3.13 & 3.28 & 2.46 & 0.01 & & \\
\hline & & $(S D)$ & $(0.57)$ & $(0.76)$ & $(0.68)$ & & & & \\
\hline Physical Competence & 5 & $M$ & 3.15 & 3.15 & 3.12 & 0.10 & 0.00 & 0.11 & 0.00 \\
\hline & & $(S D)$ & $(0.61)$ & $(0.60)$ & $(0.60)$ & & & & \\
\hline & 6 & $M$ & 3.01 & 3.02 & 3.02 & 0.00 & 0.00 & & \\
\hline & & $(S D)$ & $(0.61)$ & $(0.65)$ & $(0.71)$ & & & & \\
\hline Relationship with parents & 5 & $M$ & $3.32^{\mathrm{ab}}$ & $3.53^{\mathrm{a}}$ & $3.28^{\mathrm{b}}$ & $6.02 * *$ & 0.03 & $3.37 *$ & 0.01 \\
\hline & & $(S D)$ & $(0.71)$ & $(0.52)$ & $(0.60)$ & & & & \\
\hline & 6 & $M$ & 3.35 & 3.33 & 3.26 & 0.62 & 0.00 & & \\
\hline & & $(S D)$ & $(0.65)$ & $(0.65)$ & $(0.70)$ & & & & \\
\hline & & 76) & 0.14 & $9.15 * *$ & 0.11 & & & & \\
\hline & & & 0.04 & 0.85 & 0.04 & & & & \\
\hline Relationship with friends & 5 & $M$ & 3.23 & 3.25 & 3.17 & 0.80 & 0.00 & 2.85 & 0.01 \\
\hline & & $(S D)$ & $(0.50)$ & $(0.58)$ & $(0.57)$ & & & & \\
\hline & 6 & $M$ & 3.19 & 3.05 & 3.12 & 1.36 & 0.00 & & \\
\hline & & $(S D)$ & $(0.53)$ & $(0.54)$ & $(0.60)$ & & & & \\
\hline Global & 5 & $M$ & 3.46 & 3.54 & 3.46 & 1.20 & 0.00 & 2.01 & 0.01 \\
\hline & & $(S D)$ & $(0.47)$ & $(0.43)$ & $(0.44)$ & & & & \\
\hline & 6 & $M$ & 3.42 & 3.38 & 3.42 & 0.33 & 0.00 & & \\
\hline & & $(S D)$ & $(0.56)$ & $(0.44)$ & $(0.49)$ & & & & \\
\hline Overall self-concept & 5 & $M$ & $3.15^{b}$ & $3.32^{\mathrm{a}}$ & $3.22^{\mathrm{ab}}$ & $5.06 * *$ & 0.02 & $8.06 * * *$ & 0.04 \\
\hline & & $(S D)$ & $(0.36)$ & $(0.37)$ & $(0.35)$ & & & & \\
\hline & 6 & $M$ & 3.08 & 3.04 & 3.10 & 0.85 & 0.00 & & \\
\hline & & $(S D)$ & $(0.37)$ & $(0.41)$ & $(0.44)$ & & & & \\
\hline & & 76) & 2.14 & $51.23 * * *$ & $17.62 * * *$ & & & & \\
\hline & & & 0,30 & 1.0 & 0.98 & & & & \\
\hline
\end{tabular}

Note: ${ }^{*} p<0.05, * * p<0.01, * * * p<0.001$. The mean values on the same line with different letters are significantly different from each other. Trans1: remained in the same municipal school; Trans2: changed to another municipal school; Trans3: changed to another state school. M: Mean, SD: Standard Deviation. 
Table 3 shows the results regarding the life satisfaction factors. In the $5^{\text {th }}$ grade, significant differences were observed in family, friendship, school, comparative self and total life satisfaction with a small effect size. Except for satisfaction with the comparative self, in which Trans3 presented a higher mean value than Trans1, the Trans2 group presented a higher mean value either compared to Trans3 (friendship, family) to Trans1 (school), or to both (total). In the $6^{\text {th }}$ grade no significant differences were observed.

There was decreased satisfaction with school and overall life satisfaction after school transition. In both cases, there was an interaction effect between time and type of transition with a small size effect. For school satisfaction, all groups showed a significant reduction from the $5^{\text {th }}$ to $6^{\text {th }}$ grade, but this reduction was smaller in the group who did not change schools (Trans1). In the case of overall life satisfaction, the group who did not change schools (Trans1) did not present significant changes between the $5^{\text {th }}$ and $6^{\text {th }}$ grade, unlike the Trans2 and Trans3 groups in which a decrease is observed.

Table 3

Comparisons between the mean values for life satisfaction in the $5^{\text {th }}$ and $6^{\text {th }}$ grade according to school transition

\begin{tabular}{|c|c|c|c|c|c|c|c|c|c|}
\hline \multirow{2}{*}{ Variable } & & & \multirow{2}{*}{$\begin{array}{c}\text { Trans1 } \\
(\mathrm{n}=75)\end{array}$} & \multirow{2}{*}{$\begin{array}{c}\text { Trans2 } \\
(n=100)\end{array}$} & \multirow{2}{*}{$\begin{array}{c}\text { Trans3 } \\
(n=204)\end{array}$} & \multirow{2}{*}{$\begin{array}{c}F \\
(2,376)\end{array}$} & \multirow{2}{*}{$\eta_{p}^{2}$} & \multicolumn{2}{|c|}{ Interaction effect } \\
\hline & & & & & & & & $F(2,376)$ & $\eta_{p}^{2}$ \\
\hline \multirow[t]{4}{*}{ Family } & 5 & $M$ & $4.42^{\mathrm{ab}}$ & $4.66^{\mathrm{a}}$ & $4.39^{b}$ & $4.58 *$ & 0.02 & 1.82 & 0.01 \\
\hline & & (SD) & $(0.83)$ & $(0.45)$ & $(0.80)$ & & & & \\
\hline & 6 & $M$ & 4.42 & 4.45 & 4.32 & 1.29 & 0.00 & & \\
\hline & & $(S D)$ & $(0.60)$ & $(0.66)$ & $(0.74)$ & & & & \\
\hline \multirow[t]{4}{*}{ Friendship } & 5 & $M$ & $4.19^{a b}$ & $4.33^{a}$ & $4.07^{b}$ & $4.54^{*}$ & 0.02 & 1.36 & 0.00 \\
\hline & & $(S D)$ & $(0.78)$ & $(0.56)$ & $(0.71)$ & & & & \\
\hline & 6 & $M$ & 4.19 & 4.15 & 4.03 & 1.85 & 0.01 & & \\
\hline & & $(S D)$ & $(0.63)$ & $(0.61)$ & $(0.74)$ & & & & \\
\hline \multirow[t]{6}{*}{ School } & 5 & $M$ & $3.77^{b}$ & $4.14^{a}$ & $3.84^{b}$ & $5.87 * *$ & 0.03 & $5.58 * *$ & 0.02 \\
\hline & & $(S D)$ & $(0.86)$ & $(0.62)$ & $(0.88)$ & & & & \\
\hline & 6 & $M$ & 3.51 & 3.48 & 3.52 & 0.06 & 0.00 & & \\
\hline & & $(S D)$ & $(0.93)$ & $(0.77)$ & $(0.90)$ & & & & \\
\hline & & & $6.19 *$ & $51.67 * * *$ & $24.95 * * *$ & & & & \\
\hline & & & 0.696 & 1.0 & 0.999 & & & & \\
\hline \multirow[t]{4}{*}{ Self } & 5 & $M$ & 4.12 & 4.28 & 4.09 & 1.90 & 0.01 & 2.36 & 0.01 \\
\hline & & $(S D)$ & $(0.87)$ & $(0.63)$ & $(0.83)$ & & & & \\
\hline & 6 & $M$ & 4.12 & 3.99 & 3.98 & 0.93 & 0.00 & & \\
\hline & & $(S D)$ & $(0.73)$ & $(0.76)$ & $(0.82)$ & & & & \\
\hline \multirow[t]{4}{*}{ Comparative self } & 5 & $M$ & $2.28^{b}$ & $2.45^{\mathrm{ab}}$ & $2.60^{a}$ & $3.95 *$ & 0.02 & 1.66 & 0.00 \\
\hline & & $(S D)$ & $(0.84)$ & $(0.84)$ & $(0.87)$ & & & & \\
\hline & 6 & $M$ & 2.27 & 2.18 & 2.42 & 2.62 & 0.01 & & \\
\hline & & $(S D)$ & $(0.76)$ & $(0.96)$ & $(0.85)$ & & & & \\
\hline \multirow{6}{*}{$\begin{array}{l}\text { Overall life } \\
\text { satisfaction }\end{array}$} & 5 & $M$ & $3.71^{\mathrm{b}}$ & $3.93^{a}$ & $3.76^{b}$ & $5.12 * *$ & 0.02 & $5.09 * *$ & 0.02 \\
\hline & & $(S D)$ & $(0.57)$ & $(0.32)$ & $(0.52)$ & & & & \\
\hline & 6 & $M$ & 3.66 & 3.61 & 3.62 & 0.31 & 0.00 & & \\
\hline & & (SD) & $(0.41)$ & $(0.40)$ & $(0.48)$ & & & & \\
\hline & & & 0.62 & $30.79 * * *$ & $13.14 * * *$ & & & & \\
\hline & & & 0.16 & 1.0 & 0.95 & & & & \\
\hline
\end{tabular}

Note: ${ }^{*} p<0.05,{ }^{* *} p<0.01,{ }^{* *} p<0.001$. The mean values on the same line with different letters are significantly different from each other. Trans 1 : remained in the same municipal school; Trans2: changed to another municipal school; Trans3: changed to another state school. M: Mean, SD: Standard Deviation. 


\section{Discussion}

In Brazilian public schools, the first cycle of ES is predominantly offered by the municipal network and the second is predominantly offered by the state network. Thus, there would be three options for students changing from ESI to ESII: (1) transition at the same school; (2) change to another municipal school; (3) change to another state school. The aim of the study was to investigate the effects of the transition between ESI and ESII on academic performance, stress symptoms, social skills, self-concept and life satisfaction, taking into consideration the nature of the transition (with or without school change, with or without changing the school network). The objective was reached using an ANOVA model that combined pre-post transition measures with a variable developed from the type of transition experienced by the participants divided into three groups: permanence in the same school; change to a municipal school; change to a state school.

Comparisons between groups prior to the transition revealed significant differences. Children who would change schools, in some dimensions of self-concept (for example), presented more positive assessments than those who would not. To understand these differences, it is worth recalling that students change schools only if their school does not offer ESII. That is, in the $5^{\text {th }}$ grade they are the oldest students in the school and therefore may be treated as more mature and independent. In addition, they may feel more competent compared to younger students. This condition can contribute to more positive self-assessments, since selfconcept is based on comparative assessments between oneself and peers (Coelho \& Romão, 2017).

Results obtained by comparing the three groups in the $5^{\text {th }}$ grade before transition may reflect differential expectations in view of the school change. This happens because the school system informs the children well in advance which school they will attend. Results suggest that expectation effects were found when comparing life satisfaction, in which, apparently, the children who would move to another municipal school presented the most favorable results. In the $5^{\text {th }}$ grade, these students perceive themselves more positively regarding school achievement and their relationship with parents; they also showed greater satisfaction with school, friendships and family. Due to the absence of longitudinal studies with a Brazilian sample, it was not possible to discuss previous literature, but it can be assumed that students' most favorable perceptions may be related to their expectation of changing to schools well evaluated by IDEB, which are considered the best schools.

In contrast, children who would move to a state school had the highest mean stress symptoms in the $5^{\text {th }}$ grade. This result can be understood in terms of anticipatory anxiety in view of the double change changing school and school network. In the same line, Symonds and Galton (2014) found that many children feel scared, worried, nervous and sad before transition, but they are less anxious when the environmental differences between the two schools are small. This particularity may explain why students who change schools feel less stressed when they attend municipal schools in the $5^{\text {th }}$ grade.

Prior to the transition, children who would move to state schools showed significant stress symptoms, poorer social skills outcomes and lower indicators of academic achievement in comparison with other groups. On the one hand, this combination may increase vulnerability to school difficulties given the association between greater exposure to school stressors and fewer social skills, and on the other, worse academic outcomes (Jovarini, Leme, \& Correia-Zanini, 2018). To the extent that post-transition schools were those with lower IDEB scores because the students in these obtained lower mean values for performance in the national assessment, the children moving to these schools would be at an increased risk of academic failure in their school career, since moving to academically weaker classes is associated with decreased performance over time (Wouters, Fraine, Colpin, Damme, \& Verchueren, 2012). However, this did not happen, at least during the 11 months between the two evaluations. In the $6^{\text {th }}$ grade, children who had moved to state schools continue to perform more poorly than the other students, but their scores did not decrease. 
When comparing the evaluations of the $5^{\text {th }}$ and $6^{\text {th }}$ grades, there was no variation in academic performance, but the three groups remained stable. In the light of previous investigations, which differ on this issue (Ryan et al., 2013; Sebanc et al., 2014), we can assume, along with Akos et al. (2015), that the transition effect of reduction in student achievement is restricted to the post-transition period.

In contrast to the absence of effects on performance, there is a clear effect of transition on the children's perceptions of themselves as students and on satisfaction with school. The effects on self-concept are specific to the academic and school self-concept, which are in agreement with the review by Symonds and Galton (2014) and the results of Arens et al. (2013). Specifically, the results of decreased self-concept in mathematics are in agreement with those of Metsäpelto et al. (2017), who found a decrease in the achievement values attributed to mathematics after transition. Dimensions of self-concept that are not related to school showed stability, differing from the results of Coelho and Romão (2017).

Lower self-concept is not necessarily a negative result. This may be due to cognitive development that enables more realistic judgments and an increasing ability to make comparative assessments. Thus, there is a gradual reduction in self-concept regarding academic skills in the final years of elementary school (Wouters et al., 2012) because during adolescence the perception and adequacy of one's own behavior are related to academic skills, teacher feedback and social self-concept, which depends on peer judgment (Preckel, Niepel, Schneider, \& Brunner, 2013). The experience of transition between the $5^{\text {th }}$ and $6^{\text {th }}$ grades occurs during developmental changes in academic self-concept, in which performance self-assessments are sensitive to changes due to the school's level of demand (Wouters et al., 2012).

In summary, the analysis of the transition from a single perspective of an event common to all participants was suggestive of the absence of impact on the objective measures of performance, contrasting with the adverse psychosocial effects, according to the children's perception. Previous findings of reduced academic/school self-concept were reinforced and new information on the effects on life satisfaction were added, a variable that had not been previously investigated. The step forward in the analysis, focusing on the relationship between specific contextual changes and children's development, enabled a different view of this situation that enlightened us on how students deal with transition.

Children who did not change schools seem to have been the most protected ones during the process. Although following the general trend of decreasing self-assessments, they showed greater stability in selfconcept and life satisfaction. This result is consistent with the concept of ecological transition, according to which the transition will have a lower impact if one must deal with less significant changes (Bronfenbrenner, 1996). Other research findings suggest that context familiarity is associated with greater student access to positive information about their own academic competence, positively influencing their self-perception of school achievement (Symonds \& Galton, 2014).

Transition seems to have greatly affected school satisfaction of children who changed schools, as they showed a lower level of satisfaction. Madjar and Cohen-Malayev (2016) found positive perceptions of school environment before transition in students who changed schools, which declined faster and became equal or lower to the perception of students who remained in the same school.

Transition effects were mainly, though not exclusively, found in the group who changed to municipal schools in the $6^{\text {th }}$ grade. In the $5^{\text {th }}$ grade, these children presented more subjective indicators of satisfaction with family, school and peers, but these results changed in the $6^{\text {th }}$ grade. In the interaction analyses, their total self-assessment of social skills as well as their school self-concept and satisfaction with school decreased more than in the other groups. There seemed to have been some euphoria about the expectation of moving to a municipal school, which soon changed after transition, as noted by Madjar and Cohen-Malayev (2016). This effect may be related, at least in part, to the higher IDEB scores of the municipal schools (ESII). According to results obtained by Neal et al. (2016), the transition into academically selective learning environments seemed 
to come at some cost for psychosocial development. These authors found negative contextual effects of transition to a more demanding school on academic self-concept and school anxiety in $5^{\text {th }}$ graders. Stäbler, Dumont, Becker, and Baumert (2017) found similar results in $7^{\text {th }}$ grade students.

In the present investigation, the group that moved to state schools had a different experience, as these children moved to less demanding academic environments. On the one hand, the mean values of selfconcept and satisfaction with school of children who had moved to state schools with lower IDEB scores decreased, and on the other hand, they were no more stressed when compared with those who remained in the same school. These children even showed a higher general school self-concept after the transition when compared with peers who changed to municipal schools. These results are similar to those of Wouters et al. (2012) concerning the psychosocial effects of differences in the degree of demand between the previous school and post-transition school.

In short, regarding the school transition groups, two points stand out. The first one is that the group that did not change school showed greater stability when compared with children who had changed schools (state or municipal), which is consistent with the theoretical perspective of ecological transition and empirical observations (Symonds \& Galton, 2014). The second point is that children who belonged to the group moving to a municipal school presented the highest decrease in school self-concept and school satisfaction between the $5^{\text {th }}$ and $6^{\text {th }}$ grades. It may be assumed that the expectation about school transition for children in this group was high and that reality provided an opportunity to adjust their perceptions.

From the perspective of the variables investigated, academic performance was not directly associated with transition; the group that moved to municipal schools was different from the group that moved to state schools, probably due to the differences in the mean value for student performance (Stäbler et al., 2017). Stress symptoms were specifically associated with the expectation of moving to state schools; the possibility of a twofold change - from school and school network -, may have caused more anxiety in these children (Symonds \& Galton, 2014). The social skills of empathy and responsibility/cooperation before the transition were different from the groups that would change schools; together, these skills declined in all three groups, especially for children who moved to municipal schools. As social skills develop in interaction with the environment, it is expected that schooling may affect their developmental course (Primi, Santos, John, \& De Fruyt, 2016).

Self-concept has been lowered in the transition, either at its global level or in the dimensions that make up academic self-concept. This result, as seen, converges with the literature (Arens et al., 2013; Metsäpelto et al., 2017; Symonds \& Galton, 2014). Regarding the non-academic self-concept, only the self-concept in the relationship with the parents decreased after the transition, still only in the condition of moving to municipal school.

The perception of the social environment, assessed by the MSLSS, was higher in the group that expected to move to municipal schools, but only before the transition when children in this group were more satisfied with the school in comparison with those who would not move, and more satisfied with family and friendships when compared to those who would move to state schools. After the transition, the children in the three groups were less satisfied with school; this result requires attention as the results obtained by Oriol et al. (2017) have shown that satisfaction with the school experience would have a greater effect on subjective well-being than the support of friends and family.

The results support the idea that transition is as a long-haul process. Beginning with anticipations in the $5^{\text {th }}$ grade, students are sensitive to expectations as well as to concrete contextual conditions, which present themselves as new adaptive demands in the $6^{\text {th }}$ grade.

Among the limitations of the present study, the one related to the sample is noteworthy because it does not allow the generalization of the results, since it was limited to public-school students of a single city. Thus, the inclusion of several cities as well as private schools would provide a broader view of the subject. 
Two contributions can be pointed out. The first one is related to the elements that were added to the concept of ESI-ESII transition as an ecological transition, which strengthens and broadens the BMHD perspective to describe and understand the phenomenon. The second one is also related to the BMHD, but it is more comprehensive, affecting the meaning attributed by the researcher to the phenomenon of transition as an experience that can influence the child's development. In addition, this study has enlightened us on issues about transition that had not yet been identified, breaking expectations and opening the way for further investigations.

As for the possible implications of the results for the practice of educators, school managers, psychologists and other professionals who daily deal with elementary schools, they may benefit from the information in this study. The results show that there are opportunities for action with children since the $5^{\text {th }}$ grade in view of their expectations of transition, which is often accompanied by anticipatory anxiety. It would be desirable to provide opportunities for students to talk about their expectations of transition among themselves and between students and their teachers. This could be a way of alleviating anxieties that some experience in the $5^{\text {th }}$ grade and prepare them for the change that will occur. Simply having access to information may be helpful to facilitate transition.

\section{Contributors}

C. CASSONI contributed with literature review, data collection, analysis and interpretation of results, writing of the introduction and discussion of results. E. M. MARTURANO, A. M. FONTAINE, and V. B. R. LEME contributed wityh the conception and drafting of the study, bibliographic survey, writing of the introduction and discussion of the results, and approval of the final version of the article.

\section{References}

Akos, P., Rose, R. A., \& Orthner, D. (2015). Sociodemographic moderators of middle school transition effects on academic achievement. The Journal of Early Adolescence, 35(2), 170-198. http://dx.doi.org/10.1177/0272431614529367

Arens, A. K., Yeung, A. S., Craven, R. G., Watermann, R., \& Hasselhorn, M. (2013). Does the timing of transition matter? comparison of German students' self-perceptions before and after transition to secondary school. International Journal of Educational Research, 57, 1-11. http://dx.doi.org/10.1016/j.ijer.2012.11.001

Bronfenbrenner, U. (1996). A ecologia do desenvolvimento humano: experimentos naturais e planejados. Porto Alegre: Artmed.

Bronfenbrenner, U., \& Morris, P. A. (1998). The ecology of development processes. In R. M. Lerner (Ed.), Handbook of child psychology: theoretical models of human development (v.1, pp.993-1027). New York: Wiley.

Coelho, V. A., \& Romão, A. M. (2017). The Impact of secondary school transition on self-concept and self-esteem. Revista de Psicodidáctica, 22(2), 85-92. http://dx.doi.org/10.1016/j.psicod.2016.10.001

Forrest, C. B., Bevans, K. B., Riley, A. W., Crespo, R., \& Louis, T. A. (2013). Health and school outcomes during children's transition into adolescence. Journal of Adolescent Health, 52, 186-194. http://dx.doi.org/10.1016/j.jadohealth.2012.06.019

Freitas, L. C., \& Del Prette, Z. A. P. (2015). Social skills rating system - brazilian version: new exploratory and confirmatory factorial analyses. Avances en Psicología Latinoamericana, 33(1), 135-156. http://dx.doi.org/10.12804/apl33.01.2015.10

Gardinal-Pizato, E. C. (2010). Um estudo longitudinal de trajetórias de desempenho escolar (Tese de doutorado não-publicado), Universidade de São Paulo, Ribeirão Preto. Recuperado de http://nwww.teses.usp.br/teses/disponiveis/59/59137/tde-25112010-160638/pt-br.php

Giacomoni, C. H., \& Hutz, C. S. (2008). Escala multidimensional de satisfação de vida para crianças: estudos de construção e validação. Estudos de Psicologia (Campinas), 25(1), 23-35. http://dx.doi.org/10.1590/\$0103-166X2008000100003

Jovarini, N. V., Leme, V. B. R., \& Correia-Zanini, M. R. G. (2018). Influência das habilidades sociais e estressores sobre o desempenho escolar no $6^{\circ}$ ano. Paidéia, 28(e2819). http://dx.doi.org/10.1590/1982-4327e2819

Lipp, M. E. N., \& Lucarelli, M. D. M. (2008). Escala de Stress Infantil (ESI): Manual. São Paulo: Papirus. 
Madjar, N., \& Cohen-Malayev, M. (2016). Perceived school climate across the transition from elementary to middle school. School Psychology Quarterly, 31(2), 270-288. http://dx.doi.org/10.1037/spq0000129

Marôco, J. (2014). Análise estatística com o SPSS Statistics (6a ed.). Lisboa: ReportNumber.

Marsh, H. W., Relich, J. D., \& Smith, I. D. (1983). Self-concept: the construct validity of interpretations based upon the SDQ. Journal of Personality and Social Psychology, 45, 173-187. http://dx.doi.org/10.1037/0022-3514.45.1.173

Metsäpelto, R. L., Taskinen, P., Kracke, B., Silinskas, G., Lerkkanen, M. K., Poikkeus, A. M., \& Nurmi, J. E. (2017). Changes in achievement values from primary to lower secondary school among students with and without externalizing problems. Learning and Individual Differences, 58, 75-82. http://dx.doi.org/10.1016/.lindif.2017.08.002

Neal, S., Rice, F., Ng-Knight, T., Riglin, L., \& Frederickson, N. (2016). Exploring the longitudinal association between interventions to support the transition to secondary school and child anxiety. Journal of Adolescence, 50, 31-43. http://dx.doi.org/10.1016/j.adolescence.2016.04.003

Oriol, X., Torres, J., Miranda, R., Bilbao, M., \& Ortúzar, H. (2017). Comparing family, friends and satisfaction with school experience as predictors of SWB in children who have and have not made the transition to middle school in different countries. Children and Youth Services Review, 80, 149-156. http://dx.doi.org/10.1016/j.childyouth.2017.06.053

Pereira-Guizzo, C. S., Del Prette, A., Del Prette, Z. A. P., \& Leme, V. B. R. (2018). Programa de habilidades sociais para adolescentes em preparação para o trabalho. Psicologia Escolar e Educacional, 22(3), 573-581. http://dx.doi.org/10.1590/2175-35392018035449

Preckel, F., Niepel, C., Schneider, M., \& Brunner, M. (2013). Self-concept in adolescence: A longitudinal study on reciprocal effects of self-perceptions in academic and social domains. Journal of Adolescence, 36, 1165-1175. http://dx.doi. org/10.1016/j.adolescence.2013. 09.001.

Primi, R., Santos, D., John, O. P., \& De Fruyt, F. (2016). Development of an inventory assessing social and emotional skills in Brazilian youth. European Journal of Psychological Assessment, 32, 5-16. http://dx.doi.org/10.1027/1015-5759/a000343

Ryan, A. M., Shim, S. S., \& Makara, K. A. (2013). Changes in academic adjustment and relational self-worth across the transition to middle school. Journal Youth Adolescence, 42, 1372-1384. http://dx.doi.org/10.1007/s10964-013-9984-7

Sebanc, A. M., Guimond, A. B., \& Lutgen, J. (2014). Transactional relationships between latinos' friendship quality and academic achievement during the transition to middle school. Journal of Early Adolescence, 36(1), 108-138. http:// dx.doi.org/10.1177/0272431614556347

Stäbler, F., Dumont, H., Becker, M., \& Baumert, J. (2017). What happens to the fish's achievement in a little pond? A simultaneous analysis of class-average achievement effects on achievement and academic self-concept. Journal of Educational Psychology, 109(2), 191-207. http://dx.doi.org/10.1037/edu0000135

Symonds, J. E., \& Galton, M. (2014). Moving to the next school at age 10-14 years: an international review of psychological development at school transition. Review Education, 2(1), 1-27. http://dx.doi.org/10.1002/rev3.3021

Wouters, S., Fraine, B. D., Colpin, H., Damme, J. V., \& Verchueren, K. (2012). The effect of track changes on the development of academic self-concept in high school: a dynamic test of the big-fish-little-pond effect. Journal of Educational Pychology, 104(3), 793-805. http://dx.doi.org/10.1037/a0027732

Received: May 7, 2019

Final version: September 11, 2019

Approved: November 18, 2019 